\title{
TEČAJI ŠPANŠČINE ZA STAREJŠE ODRASLE NA UINIVERZI ZA TRETJE ŽIVLJENJSKO OBDOBJE IN V DNEVNIH CENTRIH AKTIVNOSTI ZA STAREIŠE
}

\section{POVZETEK}

$V$ članku so predstavljena teoretična izhodišča o starejših odraslih in učenju v obdobju pozne odraslosti. Avtorja menita, da je za učinkovito poučevanje starejših odraslih treba poznati njihove motive in značilnosti učenja v tem obdobju. Razloženi so različni vidiki učenja starejših odraslih in opredeljene njihove zmožnosti za učenje tujega jezika. V empiričnem delu so predstavljeni izsledki raziskave, izvedene med udeleženci začetnih in nadaljevalnih tečajev španščine na univerzi za tretje življenjsko obdobje in dnevnih centrih aktivnosti za starejše v Ljubljani v študijskem letu 2013/14. Odgovori udeležencev tečajev španščine so prikazani kot ključni za razumevanje tega, zakaj se odločajo za učenje španščine in kaj jim je pri tem pomembno, kar izobraževalcem starejših daje smernice za delo z njimi. Rezultati raziskave so pokazali, da udeleženci kot najpomembnejši razlog za udeležbo na tečaju navajajo ljubezen do jezika in možnost potovanj po špansko govorečih državah. Kot najpomembnejšo aktivnost so ocenili poslušanje učitelja in izdelavo zapiskov, vaje izgovarjave ter učenje novih besed. Pri učni skupini najvišje vrednotijo sproščeno vzdušje, medsebojno razumevanje in sodelovanje, najpomembnejše značilnosti učitelja pa so po njihovem mnenju jasna razlaga in pozitiven odnos do udeležencev ter učna podpora.

Ključne besede: izobraževanje starejših, tretje življenjsko obdobje, pozna odraslost, stereotipi o starejših, učenje jezikov $v$ starosti, poučevanje španščine

\section{SPANISH COURSES FOR OLDER ADULTS AT THE UNIVERSITY OF THE THIRD AGE AND ADULT DAY CARE CENTERS - ABSTRACT}

The article presents theoretical starting points regarding older adults and learning Spanish language in late adulthood. The starting points are based on the assumption that in order to effectively learn a foreign language in late adulthood, the definitions of the cognitive characteristics of the elderly and the characteristics of learning in this period have to be defined first. I continuation the paper explains various characteristics of learning with older adults. The main emphasis is on analyzing the ability of

Klara Zavrl, klara.zavrl@gmail.com

Izr. prof.dr. Marko Radovan, Filozofska fakulteta Univerze v Ljubljani, marko.radovan@ff.uni-lj.si 
older people to learn a foreign language and their motivation to learn. The empirical part of the paper presents the results of the survey conducted among participants in the initial and intermediate Spanish courses at the University of the Third Age and day center activities for the elderly in Ljubljana, during the academic year 2013/14. The results showed that the most important reason for attending the course were the love of language and the chance to attend trips to Spanish-speaking countries. As the most important activities in the course the participants highlighted listening to the instructor and making notes, exercises in pronunciation and learning new words. The participants valued relaxed atmosphere of mutual understanding as well as cooperation within the learning group. The most important features of a good instructor, according to the participants, are coherent explanation, positive attitude towards the participants, and learning support.

Keywords: education for elderly people, third age, late adulthood, stereotypes about elderly people, language teaching, teaching Spanish

\section{UVOD}

Učenje odraslih pogosto povezujemo z identiteto posameznika in njenim spreminjanjem (Jarvis, 2001). Te spremembe so velike še posebej ob upokojitvi, enem od najpomembnejših dogodkov v življenju posameznika. Za nekatere je sprememba identitete po upokojitvi minimalna, ker ohranijo enake vzorce delovanja, kot so jih imeli pred upokojitvijo, za druge je sprememba identitete lahko dramatična, zlasti ob zavedanju o izgubi družbenega in delovnega položaja. Če so ljudje v svojem delu našli vsebino in smisel svojega življenja, je prehod v upokojitev lahko precej stresen. Za tiste, ki jim njihovo delo ni bilo všeč ali pa jim je bilo v breme, pa pomeni upokojitev vstop v novo, prijetnejše obdobje, v katerem se lahko ukvarjajo z dejavnostmi, za katere prej niso imeli časa ali zbranosti, recimo umetnostjo, branjem knjig, poslušanjem koncertov, učenjem novega jezika in podobno. Dodatno izobraževanje jim omogočajo organizacije, kot so univerza za tretje življenjsko obdobje (UTŽO), dnevni center aktivnosti za starejše (DCA) in drugi izobraževalni programi za starejše.

\section{Pripravljenost za učenje $\mathbf{v}$ pozni odraslosti}

Motivacijo in njene značilnosti štejemo med ključne dejavnike, ki vplivajo na uspešnost pri učenju tujega jezika (Fontanella in Sandmann, 2011). Brez nje namreč tudi tisti z izjemnimi sposobnostmi ne morejo biti uspešni pri doseganju dolgoročnih ciljev. Rifai (2010) v svojem delu razlikuje dva temeljna tipa motivacije pri učenju jezika: integrativnega in instrumentalnega. Prvi je dominanten pri usvajanju prvega jezika, pri usvajanju tujega pa je njegova pomembnost relativna in odvisna od posameznika. Drugi dejavnik so sporazumevalne potrebe oziroma instrumentalna ali utilitaristična motivacija (prav tam). V tem primeru spodbujajo pripravljenost za učenje jezika specifične potrebe, kot je denimo opravljanje izpita, doseganje družbenega priznanja in ekonomske koristi. Obe motivacijski usmeritvi tvorita celoto in ju je pri posamezniku, ki se uči jezik, pogosto težko razločevati oziroma eni ali drugi pripisovati večjo ali manjšo pomembnost, saj se motivi prepletajo. 
Odnos do izobraževanja in motivacija za učenje se skozi različna življenjska obdobja spreminjata. Razni avtorji, kot so Illeris (2007), Krajnc (1992) ter Kump in Jelenc Krašovec (2009), se strinjajo, da učenje v zrelih letih ni tako ciljno usmerjeno kot učenje v mladosti, pogosto ga zaznamuje osebna notranja motivacija, brez prisilnosti ali zunanjih pritiskov, ki so pogosto vzvodi za učenje v zgodnejših obdobjih odraslosti. Učijo se tisto, kar želijo vedeti, razumeti, študirati ali uporabiti. Motivirajo jih strast do predmeta, ki se ga učijo, užitek pri učenju, krepitev samozavesti in spoznavanje ljudi. Tako kot motivacija za učenje se z leti povečuje tudi pomembnost osebnega razvoja (Aldridge in Tuckett, 2007; Findeisen, 2012; Krajnc, 2012; Requejo Osorio, 2008).

Izsledki raziskave, ki so jo opravili na Nacionalnem inštitutu za nadaljevalno izobraževanje odraslih v Veliki Britaniji (NIACE), ${ }^{1}$ kažejo, da se število ljudi, ki navajajo zanimanje za predmet, užitek pri učenju, izboljšanje samozavesti in spoznavanje ljudi, povečuje z vsakim desetletjem. Kot ključne prednosti učenja navajajo osebnostni razvoj, spoznavanje novih ljudi in prijateljev ter izboljšanje komunikacijskih spretnosti. Razlog za povečanje pomembnosti spoznavanja novih ljudi med starejšimi je lahko tudi izraz njihovega strahu pred izolacijo v starosti, ki je posledica izgube družabnih stikov po upokojitvi (Aldridge in Tuckett, 2007).

Krajnc (2009) poudarja, da je eden pogostih stereotipov, da se starejši izobražujejo predvsem zato, ker jim je sicer dolgčas in ker iščejo stike z ljudmi. Stiki so pomembni za vsakega in so eden od motivov starejših, niso pa glavni motiv. Stereotipi o starejših odraslih pri ljudeh pogosto spodbujajo vedenje, s katerim podcenjujejo potencial starejše osebe ali oseb, ki jih opazujejo ali s katerimi komunicirajo (Cavanaugh in Blanchard-Fields, 2006). V sodobnih zahodnih družbah so med negativnimi stereotipi najbolj razširjeni tisti, ki se nanašajo na spoznavno delovanje starejših (Hillier in Barrow, 2007). Negativni socialni stereotipi o starejših in njihov družbeni položaj vplivajo na to, do kakšne mere starejši uporabljajo svoje sposobnosti, torej tudi do kakšne mere uporabljajo sposobnost pomnjenja (Krajnc, 2003). Williamson (1996) je v svoji raziskavi primerjal skupino žensk in moških, udeležencev izobraževanj univerze za tretje življenjsko obdobje, in ugotovil, da ima poleg vseh dejavnikov, ki vplivajo na vključevanje starejših odraslih v izobraževanje (denimo zdravje, izobrazba, socioekonomski status in podobno), pomembno vlogo tudi socializacija spolnih vlog. Ženske imajo namreč drugačen odnos do upokojitve kot moški. Ker se v organizacije, ki ponujajo izobraževanje za starejše odrasle, ter razne prostovoljske in kulturne dejavnosti vključujejo pretežno ženske, kar vpliva tudi na izobraževalni program, ki je prilagojen bolj ženskim kot moškim interesom, je to lahko tudi eden izmed razlogov, zakaj za moške vključevanje v izobraževanje in druge aktivnosti ni tako privlačno. Kljub navedenim predsodkom se je izkazalo, da moški, ki so bili aktivni že pred upokojitvijo, ostajajo aktivni tudi v tretjem življenjskem obdobju (prav tam). Izsledki raziskave so pokazali, da se v organizirane in dlje časa trajajoče oblike izobraževanja pogosteje vključujejo ženske in starejši odrasli, stari od 50 do 65 let, z višjo stopnjo

1 Leta 2016 se je NIACE preimenoval v $»$ Learning and Work Institute « (http://www.learningandwork.org.uk/). 
izobrazbe (Kump in Jelenc Krašovec, 2014). Poleg spola in stopnje izobrazbe imajo pri pripravljenosti na sodelovanje v izobraževanju pomembno vlogo tudi pretekle zaposlitve posameznika (prav tam). Feminizacija izobraževanja starejših odraslih ni značilna samo za Slovenijo, ampak tudi za druge države (Formosa, 2012; Sargant, 2000; Withnall, McGivney, Soulsby, 2004).

\section{Sposobnost učenja v pozni odraslosti}

Učenje in spomin sta tesno povezana pojma. Učenje navadno definiramo kot usvojitev nove spretnosti ali informacije prek vaje oziroma izkušnje, medtem ko se pomnjenje definira kot priklic informacij, ki so shranjene v spominu (Schaie in Willis, 2015). Starejši ljudje so zmožni uporabljati možgane ter ohraniti sposobnost za razvoj spretnosti in produktivno aktivnost v podobni meri kot mlajši, vseživljenjsko učenje pa dokazano varuje pred kroničnimi bolezni možganov v starosti in spodbuja njihovo fleksibilnost (Guglielman, 2012; Yotsumoto, Chang, Ni, Pierce, Andersen, Watanabe in Sasaki, 2014). Predvidevanje, da se starejši ne morejo naučiti novih stvari, je povezano z nerealističnimi percepcijami, da imajo manj možganske moči kot mlajši učenci, in s tem, da so nezmožni učenja zaradi fizičnega in mentalnega upada, povezanega s starostjo (Withnal, 2004). Hitrost, s katero so se starejši zmožni naučiti novih stvari, je odvisna od kompleksnega nabora dejavnikov, ki jih je treba upoštevati, ko načrtujemo in izvajamo priložnosti za učenje. Reakcijski čas upada, a ga je z vajo možno skrajšati. Starejši udeleženci bodo morda potrebovali pomoč pri doseganju hitrosti in izboljševanju koncentracije ter pri osebnih strategijah učenja - na primer »učenje učenja «. Zmožnost starejših, da svoje bogate izkušnje pokažejo pri svojem učenju, pa je lahko velika prednost $v$ učnih situacijah, kjer hitrost odgovora ni tako pomembna (prav tam). Študije o staranju so pokazale, da sposobnost učenja s starostjo ne upada. Če starejši ostanejo zdravi, njihove intelektualne sposobnosti in spretnosti ne upadejo (Guglielman, 2012; Schaie in Willis, 2015).

\section{Starost in učenje tujega jezika}

Največja ovira za starejše $v$ jezikovnem izobraževanju je dvom - v glavi učenca in učitelja - o tem, ali se lahko starejši odrasli učijo novega jezika. Večina domneva, da imajo mlajši določene prednosti pri učenju tujih jezikov in da »mlajši ko smo, bolje je « velja tudi za učenje tujih jezikov, vendar pa so številne študije, ki so primerjale raven znanja jezika pri otrocih in odraslih, pokazale, da imajo otroci sicer prednost pri usvajanju jezika, s katerim so v stiku daljše obdobje, kot na primer z maternim, a veliko raziskav kaže, da se odrasli jezika naučijo hitreje kot otroci oziroma so pri učenju enakovredni (Bista, 2008; Muñoz, 2010; Pirih Svetina, 2005). Muñoz (2010) piše, da starejši začetniki napredujejo hitreje v prvih stopnjah procesa usvajanja tujega jezika, zaradi česar so kratkoročno bolj učinkoviti učenci, torej imajo hitrostno prednost, v nasprotju so mlajši počasnejši na začetku, dolgoročno pa dosežejo višjo stopnjo obvladovanja jezika, včasih skoraj do najvišje stopnje (Alvarado, 2008). Pirih Svetina (2005) omenja rezultate raziskav, ki so pokazali, da otroci in odrasli usvajajo strukture tujega jezika v zelo podobnem zaporedju, učeči pa se glede na starost razlikujejo tako v hitrosti kot v uspešnosti pri usvajanju tujega 
jezika, do podobnih ugotovitev so prišle tudi avtorice Fontanella in Sandmann (2011) ter Alvarado (2008).

Čeprav so raziskovalci na podlagi rezultatov empiričnih raziskav prišli do konsenza, da starost vpliva na učenje tujega jezika (prim. Mackey in Sachs, 2012), še vedno obstaja več različnih razlag, kako naj bi se to dogajalo. Larsen-Freeman in Long (1991) navajata štiri možne razlage: socialno-psihološko, kognitivno, učno in nevrofiziološko. Slednja je znana kot hipoteza o kritičnem obdobju za učenje jezika in temelji na predvidevanju, da struktura možganov v prvih desetih letih življenja, po drugih virih pa od drugega leta do pubertete, omogoča naravno, nenaporno in brezpogojno uspešno usvajanje jezika. Po tem času se struktura možganov spremeni in usvajanje jezika ni več nujno brezpogojno uspešno. Socialno-psihološka razlaga predstavlja odraslega kot nosilca različnih družbenih vlog, ki se jim kot govorec drugega jezika noče odpovedati, in z ohranjanjem izgovora, ki je blizu prvemu jeziku, kaže odrasli pripadnost svoji jezikovni skupnosti. Otroci so pri učenju tujega jezika lahko uspešnejši, ker niso obremenjeni s svojo socialno identiteto in z njo povezanimi vlogami (prav tam).

Večina strokovnjakov se strinja, da se posamezniki učijo različno glede na dejavnike, kot so učne priložnosti, motivacija za učenje, anksioznost, samozavest, individualne razlike in učni stili v usvajanju tujega jezika na različnih stopnjah (Bista, 2008). Kot navajata Lightbown in Spada (2013), je učenje odvisno od učenčevih lastnosti in okolja. Njuni izsledki kažejo na to, da starejši lažje rešujejo probleme in imajo večje metalingvistične sposobnosti kot mlajši. Drugi raziskovalci so se denimo osredotočili še na izgovarjavo, sintakso in slovnične morfeme. Snow in Hoefnagel-Hohle (1982) sta izvedla raziskavo, ki ju je pripeljala do ugotovitve, da se odrasli učijo hitreje kot otroci. Do podobnih ugotovitev sta prišla tudi Singleton in Ryan (2004), ki pravita, da je sicer izgovarjava pri mlajših učencih boljša kot pri starejših odraslih, vendar pa so se starejši udeleženci bolje odrezali pri sintaksi tako na pisnih kot ustnih testih.

\section{NAMEN RAZISKAVE}

Starejši odrasli so specifična učna skupina, ki se tujega jezika uči drugače kot mlajši (Alvarado, 2008). Da bi lahko učitelj način poučevanja čim bolj prilagodil ciljni skupini, mora dobro poznati učne potrebe starejših, njihove motive in pričakovanja, kognitivne zmožnosti in lastnosti ter njihove lastne predsodke o učenju jezika v pozni odraslosti. Iz tega razloga je bil namen raziskave ugotoviti, na podlagi katerih motivov se starejši odločajo za učenje španščine kot tujega jezika, katerim jezikovnim spretnostim bi radi posvetili največ časa, katere aktivnosti jim najbolj pomagajo pri doseganju njihovih ciljev, katere lastnosti so jim pomembne pri učni skupini in pri učitelju. 


\section{METODOLOGIJA}

\section{Udeleženci raziskave}

V raziskavo smo vključili udeležence tečajev španščine na UTŽO in DCA v Ljubljani v študijskem letu 2013/2014. Vzorec v raziskavi je priložnosten; vprašalniki so bili v tiskani obliki posredovani vsem prisotnim udeležencem tečaja. Skupaj smo prejeli 64 izpolnjenih vprašalnikov - na UTŽO je vprašalnik rešilo 27 , na DCA pa 37 udeležencev. Udeleženci tečajev so tako starejši zaposleni kot upokojeni. Najmlajši anketiranec je imel 50 let, najstarejši pa 80 let. Večina udeležencev je bila visoko izobražena, saj je imelo kar 73,4 odstotka anketirancev višjo, visoko ali univerzitetno stopnjo izobrazbe.

\section{Instrumentarij in postopek zbiranja podatkov}

Za zbiranje podatkov smo pripravili anketni vprašalnik, ki ga večinoma sestavljajo vprašanja zaprtega tipa, dve polodprti in eno odprto vprašanje. V vprašalniku so tudi trije sklopi trditev, pri katerih so anketirani na petstopenjski lestvici ocenili pomembnost aktivnosti ter lastnosti učitelja in učne skupine pri učenju španščine.

Iskanja anketirancev smo se lotili s kontaktiranjem vodij oziroma koordinatorjev univerze za tretje življenjsko obdobje in dnevnih centrov aktivnosti v Ljubljani. Ko smo dobili potrditev, da lahko opravimo anketo med njihovimi udeleženci, smo se z učitelji španščine starejših odraslih dogovorili za dan izvedbe ankete. Na dnevnih centrih aktivnosti smo po predstavitvi namena raziskave anketo izvajali osebno pred začetkom ali pred koncem učne ure španskega jezika, medtem ko je na univerzi za tretje življenjsko obdobje anketne vprašalnike prevzela učiteljica oziroma mentorica in jih razdelila med udeležence, ki so anketo nato rešili doma in jo na naslednji uri vrnili mentorici. Ta je udeležencem sama predstavila namen raziskave. Proces zbiranja podatkov od dogovarjanja za izvedo ankete do same izvedbe in prevzema vprašalnikov je trajal tri mesece, podatke smo zbirali od marca do maja 2014.

\section{REZULTATI}

\section{Razlogi oziroma motivi starejših za učenje španščine}

Starejši odrasli imajo za učenje tujega jezika različne motive. Da bi te motive lahko upoštevali tudi pri načrtovanju jezikovnega programa in poučevanju, nas je v raziskavi zanimalo, kakšni so razlogi tečajnikov za obiskovanje tečaja španščine. Anketiranci so lahko pri tem vprašanju izbrali več odgovorov. 
Tabela 1: Motivi, zaradi katerih se odločajo za učenje španščine

\begin{tabular}{|l|c|c|}
\hline Motivi & $f$ & $f \%$ \\
\hline Ker mi je ta jezik všeč & 49 & 76,6 \\
\hline Zaradi potovani po špansko govorečih deželah & 38 & 59,4 \\
\hline Zaradi aktivnega preživljanja prostega časa & 27 & 42,2 \\
\hline Na splošno mi je všeč učenje tujih jezikov & 25 & 39,1 \\
\hline Da bi se lažje sporazumeval/a s špansko govorečimi & 21 & 32,8 \\
\hline Rad/a bi bolje spoznal/a špansko in latinskoameriško kulturo & 18 & 28,1 \\
\hline Da bi lahko bral/a revije, časopise in drugo literaturo v španščini & 17 & 26,6 \\
\hline Zaradi druženja s sotečajniki & 11 & 17,2 \\
\hline Da bi lažje spremljal/a TV-programe v španščini & 9 & 14,1 \\
\hline
\end{tabular}

Najpomembnejši razlog za udeležbo na tečaju je bila ljubezen do jezika. Več kot tri četrtine anketirancev je navedlo ta razlog. Drugi najpogostejši razlog so potovanja po špansko govorečih deželah, kot sta Španija in Latinska Amerika, zaradi tega se je za učenje tujega jezika odločilo 59,4 odstotka anketiranih. Ob zmanjšanju delovnih in družinskih obveznosti ter vse dostopnejših potovanjih tudi v bolj oddaljene kraje ne preseneča, da je to eden izmed pogostejših razlogov za učenje tujega jezika. Pri 42,2 odstotka anketiranih je pomemben razlog tudi aktivno preživljanje prostega časa, 39,1 odstotka jih navaja, da so se za učenje španščine odločili, ker jim je na splošno všeč učenje tujih jezikov, 32,8 odstotka pa zato, da bi se lažje sporazumevali s špansko govorečimi (na primer sorodniki in prijatelji). Sledijo poznavanje španske in latinskoameriške kulture, za ta odgovor se je odločilo 28,1 odstotka anketirancev, branje revij, časopisov, knjig in druge literature v španščini (26,6 odstotka) ter druženje s sotečajniki (17,2 odstotka). Najmanj pogosto so kot razlog navedli lažje spremljanje televizijskih programov. V literaturi pogosto zasledimo ugotovitve, da se starejši za izobraževanje odločajo, ker iščejo stike z drugimi ljudmi (npr. Kim in Merriam, 2004; Jelenc Krašovec in Kump, 2009; Ostiguy, Hopp in MacNeil, 1998), a je druženje kot razlog za učenje španščine izbralo le 17,2 odstotka anketirancev, kar kaže na to, da gre le še za enega od stereotipov o starejših odraslih. Druženje je za starejše odrasle pomembno, a v našem vzorcu ni najpomembnejši motiv za vključitev v izobraževanje.

\section{Mnenje udeležencev o jezikovnih spretnostih}

Poučevanje jezika temelji na štirih jezikovnih spretnostih: govornem izražanju, bralnem razumevanju, slušnem razumevanju in pisnem izražanju. Ugotoviti smo želeli, katerim jezikovnim spretnostim po mnenju udeležencev na tečaju posvečajo največ časa. Tudi pri tem vprašanju je bilo možnih več odgovorov. 
Tabela 2: Jezikovne spretnosti, ki jim po mnenju udeležencev na tečaju posvečajo največ časa

\begin{tabular}{|l|r|r|}
\hline Jezikovna spretnost & $f$ & $f \%$ \\
\hline Govorno izražanje & 52 & 81,3 \\
\hline Bralno razumevanje & 42 & 65,6 \\
\hline Slušno razumevanje & 23 & 35,9 \\
\hline Pisno izražanje & 12 & 18,8 \\
\hline
\end{tabular}

Po mnenju 81,3 odstotka starejših udeležencev na tečaju največ časa namenjajo govornemu izražanju, in sicer skozi aktivnosti govorjenja, dialogov, ustnih predstavitev in podobno. Na drugem mestu je bralno razumevanje (branje besedil, zgodbic, člankov, revij ...), za katerega se je odločilo 65,6 odstotka vprašanih, sledi slušno razumevanje, to je razumevanje posnetih besedil, pesmi in drugo ( 35,9 odstotka), najmanj časa pa se po njihovem mnenju namenja pisnemu izražanju (pisanju pisem, krajših in daljših besedil, nareku ...), za katerega se je odločilo 18,8 odstotka anketirancev.

V spodnji tabeli prikazujemo rekodirane odgovore na vprašanje, katerim jezikovnim spretnostim bi želeli na tečaju posvetiti več časa.

Tabela 3: Jezikovna spretnost, ki bi ji na tečaju želeli nameniti več časa

\begin{tabular}{|l|r|r|}
\hline Jezikovna spretnost & $f$ & $f \%$ \\
\hline Govorno izražanje & 29 & 74,4 \\
\hline Slušno razumevanje & 13 & 33,3 \\
\hline Bralno razumevanje & 6 & 15,4 \\
\hline Pisno izražanje & 3 & 7,7 \\
\hline
\end{tabular}

Anketiranci so v 74,4 odstotka odgovorili, da bi se želeli še več časa ukvarjati z govornim izražanjem, 33,3 odstotka pa bi jih želelo več časa posvetiti tudi slušnemu razumevanju. Glede na to, da smo predvidevali, da na tečajih največ časa posvečajo govornemu izražanju, smo pričakovali, da bi poleg govornega izražanja želeli več časa posvetiti slušnemu razumevanju, a se je pokazalo, da bi si vseeno želeli še več govornega izražanja. Konverzacija je vsekakor izredno pomemben del učenja tujega jezika, sledita bralno razumevanje in pisno izražanje. Glede na rezultat lahko predvidevamo, da se starejšim odraslim zdita govorno izražanje in slušno razumevanje pomembnejši oziroma uporabnejši jezikovni spretnosti, posledično pa bi jima želeli posvečati tudi največ časa.

\section{Mnenje udeležencev o pomembnosti aktivnosti pri učenju španščine}

Pri poučevanju tujega jezika se uporabljajo različne aktivnosti. Kako te vidijo tečajniki in katere so tiste aktivnosti, ki se starejšim zdijo najpomembnejše pri učenju španščine? Anketiranci so pomembnost aktivnosti ocenjevali po petstopenjski lestvici (1 - ni pomembno do 5 - zelo pomembno). 
Tabela 4: Pomembnost aktivnosti za udeležence

\begin{tabular}{|l|r|r|}
\hline Aktivnosti & $\overline{\mathbf{x}}$ & SD \\
\hline Poslušanje učitelja in delanje zapiskov & 4,56 & 0,690 \\
\hline Vaje izgovarjave & 4,51 & 0,648 \\
\hline Učenje novih besed & 4,41 & 0,710 \\
\hline Pogovor s sotečajniki ali učiteljem v španščini & 4,38 & 0,738 \\
\hline Učenje in vaje iz slovnice & 4,38 & 0,738 \\
\hline Vaje za aktivno preverjanje znanja & 4,32 & 0,748 \\
\hline Domače naloge & 4,25 & 0,842 \\
\hline Ustne predstavitve & 4,12 & 0,727 \\
\hline Pisanje krajših sestavkov, zgodb ipd. & 3,97 & 0,897 \\
\hline Branje člankov, zgodb ipd. & 3,64 & 0,942 \\
\hline Učenje in utrjevanje prek iger & 3,55 & 0,977 \\
\hline Poslušanje in delo s CD-posnetki (pesmi, dialogi itd.) & 3,53 & 1,051 \\
\hline Gledanje filmov, posnetkov ipd. & 3,22 & 0,991 \\
\hline Igra vlog & 3,18 & 0,947 \\
\hline Projektno delo (organizacija literarnega večera, izleta itd.) & 3,14 & 1,125 \\
\hline
\end{tabular}

Legenda: $\bar{x}=$ povprečna vrednost, $S D=$ standardna deviacija

Ker je pri učenju tujega jezika glavni cilj zmožnost sporazumevanja v tujem jeziku, smo predvidevali, da starejši odrasli izmed vseh aktivnosti pogovor v španskem jeziku s sotečajniki ali učiteljem označujejo kot najpomembnejšega, a se naše predvidevanje ni potrdilo, saj so kot najpomembnejšo aktivnost ocenili poslušanje učitelja in delanje zapiskov, vaje izgovarjave ter učenje novih besed, kar je možno pripisati tudi načinu poučevanja tujega jezika in metodam, ki so jih bili vajeni v preteklosti. Pogovor s sotečajniki ali učiteljem v španščini je po pomembnosti na četrtem mestu, sledijo učenje in vaje iz slovnice, vaje za aktivno preverjanje znanja in druge aktivnosti. Razlog za nižjo oceno nekaterih aktivnosti je lahko tudi ta, da s temi dejavnostmi nimajo toliko izkušenj in jih zato ocenjujejo kot manj pomembne.

\section{Mnenje udeležencev o lastnostih učne skupine}

Za starejše odrasle je pomembna tudi učna skupina, zato nas je zanimalo, kako starejši po pomembnosti ocenjujejo lastnosti učne skupine. 
Tabela 5: Pomembne značilnosti učne skupine

\begin{tabular}{|l|r|r|}
\hline & $\overline{\mathbf{x}}$ & \multicolumn{1}{|c|}{ SD } \\
\hline Sproščeno vzdušje, razumevanje in sodelovanje & 4,57 & 0,559 \\
\hline Aktivna vloga v učnem procesu & 4,35 & 0,786 \\
\hline Solidarnost in upoštevanje drug drugega & 4,29 & 0,776 \\
\hline Enaka možnost izražanja & 4,27 & 0,709 \\
\hline Podobna stopnja predznanja & 3,84 & 1,003 \\
\hline Pripadnost skupini & 3,28 & 1,097 \\
\hline Sodelovanje pri odločanju o ciljih, vsebinah in učnih metodah & 3,20 & 0,996 \\
\hline Podobni cilii udeležencev & 3,19 & 1,191 \\
\hline Načrtovanje skupne aktivnosti zunaj učnih ur & 2,49 & 0,971 \\
\hline
\end{tabular}

Legenda: $\bar{x}=$ povprečna vrednost, $S D=$ standardna deviacija

Kot najpomembnejšo lastnost učne skupine so starejši navedli sproščeno vzdušje, medsebojno razumevanje in sodelovanje. Tudi v naši raziskavi se je pokazalo, da je aktivna vloga $v$ učnem procesu precej pomembna. Sledijo solidarnost in upoštevanje drug drugega, enaka možnost izražanja in podobna stopnja predznanja udeležencev. Odrasli načeloma dajejo prednost izkustvenim in skupinskim oblikam ter metodam izobraževanja (Caminotti in Gray, 2012; Davis, 2013; Goddu, 2012). To zagotovo velja tudi za starejše odrasle, saj lahko tako rešujejo tudi nekatere druge težave, kot so osamljenost, pomanjkanje občutka pripadnosti neki socialni skupini in potreba po uveljavljanju. V naši raziskavi so udeleženci pripadnost učni skupini v povprečju ocenili s 3,28 , sodelovanje pri odločanju o ciljih, vsebinah, učnih metodah in podobno s 3,20 , podobne cilje udeležencev s 3,19 , kot najmanj pomembno pa so udeleženci ocenili načrtovanje skupne aktivnosti zunaj učnih ur, morda tudi zato, ker z aktivnostmi zunaj organiziranega tečaja nimajo toliko izkušenj.

\section{Mnenje udeležencev o lastnostih učitelja}

Učitelj starejših odraslih ima drugačno vlogo kot učitelj mlajših učnih skupin, zato smo želeli izvedeti, katere so tiste lastnosti učitelja, ki so pomembne starejšim odraslim oziroma koliko so zanje pomembne izbrane lastnosti.

Po mnenju udeležencev naše raziskave mora znati učitelj jasno razlagati in imeti pozitiven odnos do učenja v pozni odraslosti, jih znati motivirati, spodbujati in jim dajati oporo. Kot piše Findeisen (1992), imajo strokovne reference v očeh udeležencev UTŽO velik pomen in jim povečujejo občutek lastne pomembnosti v družbi. Visoko ocenjujejo tudi sprotno popravljanje vseh napak, enake možnosti za sodelovanje in učiteljevo navdušenost in interes za poučevanje. Glede na rezultate lahko sklenemo, da so večino navedenih lastnosti učitelja učenci ocenili kot pomembno ali zelo pomembno, kar pomeni, da imajo do učiteljevih lastnosti precej visoka pričakovanja. 
Tabela 6: Pomembnost učiteljevih lastnosti za udeležence

\begin{tabular}{|c|c|c|}
\hline & $\bar{x}$ & SD \\
\hline Da vse jasno razloži & 4,66 & 0,544 \\
\hline Da nas zna motivirati in spodbujati pri učenju & 4,45 & 0,716 \\
\hline Da sproti popravlja vse naše napake & 4,43 & 0,647 \\
\hline Da vsem da enako možnost za sodelovanje & 4,42 & 0,743 \\
\hline Da sam kaže navdušenje in interes za poučevanje & 4,35 & 0,726 \\
\hline Da je dobro pripravljen na učno uro & 4,35 & 0,684 \\
\hline Da večkrat ponovi in razloži isto snov & 4,32 & 0,719 \\
\hline Da zna popestriti uro z raznolikimi aktivnostmi & 4,27 & 0,805 \\
\hline Da je potrpežljiv & 4,16 & 0,827 \\
\hline Da je točen in ne zamuja & 4,08 & 0,876 \\
\hline $\begin{array}{l}\text { Da nam pokaže, kakšne strategije lahko upora- } \\
\text { bljamo pri učenju }\end{array}$ & 4,02 & 0,806 \\
\hline $\begin{array}{l}\text { Da zna odreagirati na nepričakovane situacije pri } \\
\text { poučevanju in jim prilagodi svoj program }\end{array}$ & 4,02 & 0,778 \\
\hline Da ima smisel za humor & 3,94 & 0,903 \\
\hline Da ima strokovne reference in veliko izkušenj & 3,76 & 0,923 \\
\hline Da nam pomaga razmišljati o učnem procesu & 3,70 & 1,046 \\
\hline
\end{tabular}

Legenda: $\bar{x}=$ povprečna vrednost, $S D=$ standardna deviacija

\section{SKLEP}

V raziskavi smo ugotavljali razloge dveh skupin starejših odraslih za vključitev v jezikovni tečaj in njihova pričakovanja glede aktivnosti, učne skupine in učitelja. Ugotovili smo, da so se anketiranci za učenje španščine kot tujega jezika najpogosteje odločili zaradi lastnega interesa. Pri starejših odraslih je vedoželjnost manj povezana z zadovoljitvijo potreb po znanju, ker je zanje učenje lahko način življenja, lahko je že samo po sebi cilj. Starejši odrasli, ki so že končali kariero, imajo na razpolago več časa in priložnosti za potovanja, ki so eden najboljših načinov za preizkušanje znanja tujega jezika in tudi za njegovo izboljšanje (Anderson, 2012). Potovanja so poleg samega zanimanja za jezik drugi najpogostejši razlog za učenje španščine. Ugotovili smo tudi, da se po mnenju udeležencev na tečajih španščine največ časa namenja govornemu izražanju in bralnemu razumevanju. Tako kot za vse odrasle udeležence je tudi za starejše odrasle pri učenju cilj zmožnost govorjenja jezika. Tudi poslušanje je še posebej pomembno, branje je na tretjem mestu, pisanje pa na zadnjem. Glede na navedbe v literaturi (prim. Fujishin, 2013; Sidwell, 1987) se ta vrstni red tudi ujema z naravo uporabe jezika, saj ocenjujejo, da 45 odstotkov časa poslušamo, 30 odstotkov časa govorimo, 16 odstotkov časa beremo in devet odstotkov časa pišemo. 
Kot najpomembnejše lastnosti skupine navajajo sproščeno vzdušje in medsebojno razumevanje, sodelovanje, to, da imajo aktivno vlogo v učnem procesu, da so solidarni in upoštevajo drug drugega. Glede na naše izsledke so odnosi v skupini in učna klima izjemnega pomena in jim velja že ob začetku tečaja nameniti več pozornosti.

Za odrasle niso nujno potrebne drugačne metode poučevanja kot pri mlajših skupinah, čeprav morajo biti učitelji odraslih vseh starosti precej izkušeni pri uporabi znanja in spretnosti svojih študentov. Starejši imajo ogromno znanja in izkušenj, ki lahko presegajo izkušnje učitelja, kar mora ta sprejeti. Prav tako mora biti seznanjen z raznolikimi tehnikami poučevanja (Jarvis, 2001). Od učitelja udeleženci pričakujejo predvsem jasno razlago, veliko pa jim pomenita tudi motiviranje in spodbuda pri učenju.

Rezultati naše raziskave so omejeni z nekaterimi slabostmi. Zaradi majhnosti vzorca težko sklepamo o nekih splošnih motivih in pričakovanjih drugih starejših odraslih. Mnenja in pričakovanja udeležencev raziskave se od splošne populacije nekoliko razlikujejo tudi zaradi lokacije tečajev (urbano okolje), ki je specifična. Prav tako so v raziskavi (kot tudi na splošno v tečajih za to ciljno skupino) prevladovali višje izobraženi odrasli.

Če povežemo rezultate naše raziskave z rezultati raziskav, ki so jih opravili drugi strokovnjaki na tem področju, lahko sklenemo, da imajo mlajši udeleženci sicer boljše biološke dispozicije za učenje tujega jezika, kljub temu pa starejši odrasli pri učenju tujih jezikov ob primernih metodah poučevanja ne zaostajajo za njimi, saj v proces izobraževanja prinesejo številne prednosti (Bista, 2008; Muñoz, 2010; Pirih Svetina, 2005). Bolje razumejo slovnična pravila, saj se dobro zavedajo pravil in struktur v lastnem jeziku. Prav tako so bolj kognitivno zreli (Muñoz, 2010), zmožni so asociacij in posplošitev višjega reda in lahko vključijo vnos oziroma input novega jezika v svojo že obstoječo učno izkušnjo. Tudi usmerjenost vase, življenjske izkušnje, neodvisnost pri učenju in notranja motivacija za učenje starejšim dajejo prednost pri učenju tujega jezika. Program, ki upošteva potrebe in specifičnost ciljne skupine, je lahko zelo uspešen in vodi do hitrega usvajanja jezika, hkrati pa pomeni zanimivo in aktivno delovanje $\mathrm{v}$ starosti.

\section{LITERATURA}

Aldridge, F. in Tuckett, A. (2007). What older people learn: The whys and wherefores of older people learning. Leichester: National Institute of Adult Continuing Education.

Alvarado, C. L. (2008). Enseñanza de español como segunda lengua para adultos mayores: algunas consideraciones. Revista de Filología y Linguística de la Universidad de Costa Rica, 34(2), 89-105.

Anderson, J. (2012). Expanding Horizons: New Languages for the Elderly. Pridobljeno s http://www. aplaceformom.com/blog/new-languages-for-the-elderly/.

Bista, K. K. (2008). Age as an Affective Factor in Second Language Acquisition. English for Specific Purposes World, 21(5), 1-15.

Caminotti, E. in Gray, J. (2012). The Effectiveness of Storytelling on Adult Learning. Journal Of Workplace Learning, 24(6), 430-438.

Cavanaugh, J. C. in Blanchard-Fields, F. (2006). Adult development and aging. Belmont: Wadsworth. 
Davis, H. S. (2013). Discussion as a Bridge: Strategies that Engage Adolescent and Adult Learning Styles in the Postsecondary Classroom. Journal of The Scholarship of Teaching and Learning, 13(1), 68-76

Findeisen, D. (1992). Čemu majhne skupine v izobraževanju starejših odraslih. V A. Krajnc, idr. (ur.). Kako smo snovali Slovensko univerzo za tretje življenjsko obdobje (str. 131-154). Ljubljana: Univerza za tretje življenjsko obdobje.

Findeisen, D. (1999). Izobraževanje odraslih v njihovih poznejših letih (Doktorska disertacija). Ljubljana: Univerza v Ljubljani, Filozofska fakulteta.

Findeisen, D. (2009). Izobraževanje starejših odraslih in pomen njihovega izobraževanja za njih same ter družbo. Andragoška spoznanja, 15(3), 12-21.

Findeisen, D. (2012). Posebna narava izobraževanja starejših, izvor in razvoj konceptov in prakse v evropskem prostoru. V D. Findeisen (ur.), Posebnosti izobraževanja starejših (str. 33-43). Ljubljana: Društvo za tretje življenjsko obdobje.

Fontanella, P. in Sandmann, F. (2011). Ensenanza de una lengua extranjera a adultos mayores. Lenguas Modernas, 37, 55-62.

Formosa, M. (2012). Critical Geragogy: Situating Theory in Practice. Sodobna pedagogika, 12(5), $36-54$.

Fujishin, R. (2013). Creating Effective Groups: The Art of Small Group Communication. Maryland: The Rowman \& Littlefield Publishers.

Goddu, K. (2012). Meeting the Challenge: Teaching Strategies for Adult Learners. Kappa Delta Pi Record, 48(4), 169-173.

Guglielman, E. (2012). The Ageing Brain: Neuroplasticity and Lifelong Learning. eLearning Papers, 29(29), 1-7.

Hillier, S. M. in Barrow, G. M. (2007). Aging, the individual, and society. Belmont: Thomson.

Illeris, K. (2007). How We Learn: Learning and Non-Learning in School and Beyond. New York: Routledge.

Jarvis, P. (2001). Learning in later life: An introduction for educators \& carers. London: Kogan Page.

Jelenc Krašovec, S. in Kump, S. (2009). Adult Learning Activities, Social Networks and Different Neighbourhoods. European Societies, 11(2), 257-282. Pridobljeno s http://doi. org/10.1080/14616690802209705.

Kim, A. in Merriam, S. B. (2004). Motivations for Learning Among Older Adults in a Learning in Retirement Institute. Educational Gerontology, 30(6), 441-455. Pridobljeno s http://doi. org/10.1080/03601270490445069.

Krajnc, A. (1992). Vrste in namen izobraževanja v tretjem življenjskem obdobju. V A. Krajnc, idr. (ur.), Kako smo snovali Slovensko univerzo za tretje življenjsko obdobje (str. 57-69). Ljubljana: Univerza za tretje življenjsko obdobje.

Krajnc, A. (2003). Izobraževanje in spominjanje v tretjem življenjskem obdobju. V A. Kogoj (ur.), Spomin: zbornik prispevkov, 3. psihogeriatrično srečanje, Otočec, 13. in 14. marec 2003 (str. 111-123). Ljubljana: Spominčica - združenje za pomoč pri demenci.

Krajnc, A. (2009). Vpliv izobraževanja starejših na motivacijo za izobraževanje ostalih generacij. Andragoška spoznanja, 15(3), 31-39.

Krajnc, A. (2012). Older adults as a special learner audience. V S. Jelenc-Krašovec in M. Radovan (ur.), Conference of the ESREA Network on Education and Learning of Older Adults (str. 4-19). Ljubljana: Znanstvena založba Filozofske fakultete. Pridobljeno s http://eloa2012.pedagogika-andragogika.com.

Kump, S. in Jelenc Krašovec, S. (2010). Prestari za učenje? Ljubljana: Pedagoški inštitut in Znanstvena založba Filozofske fakultete. 
Larsen-Freeman, D. in Long, M. H. (1991). An introduction to second language acquisition research. New York: Longman.

Lightbown, P. in Spada, N. (2013). How languages are learned. New York: Oxford University Press.

Mackey, A. in Sachs, R. (2012). Older Learners in SLA Research: A First Look at Working Memory, Feedback, and L2 Development. Language Learning, 62(3), 704-740.

Muñoz, C. (2010). On how age affects foreign language learning. Pridobljeno s http://www.enl. auth.gr/ gala/14th/Papers/Invited\%20Speakers/Munoz.pdf.

Muñoz, C. in Singelton, D. (2011). A critical review of age-related research on L2 ultimate attaintment. Language Teaching, 44(1), 1-35.

O`Grady, W. D., Dobrovolsky, M. in Katamba, F. (1997). Contemporary linguistics: An introduction. London: Longman.

Ostiguy, L., Hopp, R. in MacNeil, R. (1998). Participation in lifelong learning programs by older adults. Ageing International, 24(2-3), 10-23. Pridobljeno s http://doi.org/10.1007/s12126-998-1002-0.

Pečjak, V. (1998). Psihologija tretjega življenjskega obdobja. Ljubljana: Znanstveni inštitut Filozofske fakultete Univerze v Ljubljani.

Pečjak, V. (2007). Psihologija staranja. Bled: samozaložba.

Pirih Svetina, N. (2005). Slovenščina kot tuji jezik. Domžale: Izolit.

Requejo Osorio, A. (2008). The learning of the elderly and the profile of the adult educator. Convergence, $41,2 / 3$.

Rifai, N. A. (2010). Attitude, motivation, and difficulties involved in learning the English language and factors that affect motivation in learning it. Procedia - Social and Behavioral Sciences, 2(2), 5216-5227. Pridobljeno s http://doi.org/10.1016/j.sbspro.2010.03.849.

Sagadin, J. (1991). Razprave iz pedagoške metodologije. Ljubljana: Znanstveni inštitut Filozofske fakultete.

Sargant, N. (2000). The learning divide revisited. Leicester: NIACE.

Schaie, K. W. in Willis, S. L. (2015). Handbook of the Psychology of Aging. New York: Academic Press.

Sidwell, D. (1987). Modern language learning: Adult learning strategies and approaches. Leicester: NIACE.

Singleton, D. M. in Ryan, L. (2004). Language Acquisition: The Age Factor. Clevedon: Multilingual Matters Limited.

Snow, C. in Hoefnagel-Hoehle, M. (1982). The critical period for language acquisition: Evidence from second language learning. V S. Krashen, R. Scarcella in M. Long (ur.), Child-Adult Differences in Second Language Acquisition (str. 93-111). Rowley: Newbury House.

Šircelj, M. (2009). Staranje prebivalstva v Sloveniji. V Starejši ljudje v družbi sprememb (str. 15-43). Maribor: Aristej.

Yotsumoto, Y., Chang, L.-H., Ni, R., Pierce, R., Andersen, G. J., Watanabe, T. in Sasaki, Y. (2014). White matter in the older brain is more plastic than in the younger brain. Nature Communications, 5 , 1-8. Pridobljeno s http://doi.org/10.1038/ncomms6504.

Zupančič, M., Colnerič, B. in Horvat, M. (2010). Poznavanje dejstev in zmotna prepričanja o starejših: implikacije za izobraževanje in delo s starejšimi. Andragoška spoznanja, 16(2), 37-51.

Williamson, A. (1996). Gender Issues in Older Adults ' Participation in Learning: Viewpoints and Experiences of Learners in the University of the Third Age (U3A). Educational Gerontology, 26(1), 49-66.

Withnall, A., McGivney, V. in Soulsby, J. (2004). Older people learning: myths and realities. Leicester: NIACE.

Withnall, A. (2010). Improving learning in later life. New York: Routledge. 